\title{
CULTURAL VALUES OF POLITENESS IN EFL CLASSROOM: A STUDY OF ETNOGRAPHY OF COMMUNICATION
}

\author{
Fitriyah¹, Emzir², Sakura Ridwan ${ }^{3}$ \\ 1, 2, 3Universitas Negeri Jakarta (UNJ), Jakarta, Indonesia \\ E-mail: fimasy74@gmail.com
}

Received: 09 November 2019

Accepted: 05 December 2019

\begin{abstract}
One of the purposes of learning English as a foreign language (EFL) is to be able to communicate. The Students must have communicative competence that does not only consist of linguistic competencies, but also socio-cultural ones. This paper aims to analyse the cultural themes of politeness strategies in EFL Classroom. The research in this paper focused on directive and expressive speech acts in EFL classroom. The participants of this study are three lecturers and the students of three English classes. The data are gathered by video audio by recording the lecturers' utterances and students' compliances to the lecturer, in order to find the politeness strategies and the cultural values in EFL classroom. The results show that; 1) There are seven kinds of cultural values of politeness strategies in EFL classroom, such as glorifying God, agreement, apologising, questioning, delivering praise, delivering thank you, and praying for others, 2) The lecturers and students dominantly use agreement and questioning in EFL Classroom. Thereby, this issue is relevant to EFL classes focusing on the improvement of both lecturers and students' language and cultural skill. The analytical tool refers to the theories of Brown and Levinson's positive and negative politeness, and the ethnography of communication method. The findings of this study will probably give insights into the pragmatic and conversational rules of EFL. The last part of this paper aims at summarizing that the implications that this paper are relevant to the strategies of teaching English as a Foreign Language.
\end{abstract}

Keywords: cultural values, politeness strategy, EFL Classroom

\section{Introduction}

Teaching a language is not merely teaching its syntactic or semantic properties dealing with the formal structures of language out of context. Focusing only on structural properties and meanings of isolated words does not lead to a communicative way of learning, the purpose of all modern theories of learning and teaching leading to effective learning in its real sense. To learn a language communicatively, one must know the rules governing the language beyond its structural properties; rules helping the learner to take into consideration the person whom he is talking with, paying attention to the situation, acting in the way required, and choosing the best way of conveying the message so as not to ruin the self-image of others. Since different languages call for different ways of approaching, the teaching situation must be a in a way providing opportunities for the learner to compare his L1 with the second or foreign language he is learning. (Farrokhi \& Arghami, 2017). That is why understanding the discourse of manners and how thorough politeness affects all aspects of daily social 
interaction among students themselves can lead to a deeper understanding and awareness of politeness in the target language.

One of the purposes of learning English as a foreign language (EFL) is to be able to communicate. Students must have communicative competence that does not only consist of linguistic competencies, but also socio-cultural competencies, interactions, formulas and strategies (Celce-murcia, 2007). Kasper in Senowarsito (2013) says that sociocultural, interactional, and strategic competencies refer to the speaker's pragmatic knowledge. Pragmatic perspectives can be specifically defined as knowledge of communicative actions and how to apply them, and the ability to use language appropriately in context.

Since 1970s, lots of scholars both home and abroad have been conducting the studies of teachers' language. According to Ellis (1997), teachers' language can be termed as teachers' talk, speech, or utterance, all about the language use in class. English classrooms are places where different cultures interact. Students learn about new cultures. When students enter a language class, they bring along their own cultural background and experience, which may be different from their teacher and classmates. Often students do not realize the importance of culture in language learning. A teacher (educator) not only has the responsibility to introduce students to foreign cultures and languages, but also has an obligation to realize the cultural impact on students' daily lives.

Normally in EFL classrooms, teachers are unavoidable to correct something that a student has said, done, or written. When this correction involves a negative evaluation of a student's trying, a face-threatening act happens. When the student is asked for further explanations, teachers" instructions might be a threat to him/ her because teachers are threatening the student's freedom of action, thus further threaten his/her negative face. Teachers " offering for help might also regarded as an FTA because it threatens students" negative face when teachers suggest that students may owe a debt to teachers and threaten students" positive face when teachers imply that students need help (Peng, Xie, \& Cai, 2014).

Based on this phenomenon of teacher's speech acts to students' compliance in the context of politeness, it is believed that teacher's politeness has an indirect effect on student compliance intention to enhance desired outcomes in the classroom. As it is found in some researches that speaker's politeness relates to the hearer's compliance. According to Zhang (2009), teachers' high politeness id found to be more likely to elicit positive emotions such as happiness and lead to compliance and vice versa to the low politeness that evoked negative emotions and causes resistance.

This study is based on the researchers' observation of lecturers' utterances and students' compliances in EFL at Islamic college Jakarta, it is not as expected. Some of lecturers use impolite utterances to their students and the impolite utterances affect the students' compliances. Being polite in classroom interaction is very important to create effective teaching learning process. It can be shown by using some strategies of politeness. In this research, the effects of lecturers' politeness on students' compliance are the focus of the study.

\section{Literature Review}

Some theories of Politeness proposed by Lakoff, Grice, and Leech are presented below.

\section{a) Robin Lakoff's Theory}

Lakoff as quoted by Watts (2005) claims that there are three rules in using the language so that the language can be said polite. These rules are introduced based on the strategy "How 
to use language politely": Distance of Formality (in which formal/impersonal politeness strategy are used); deference or hesitancy (in which options are given to the addressed); Informality of camaraderie (where intimacy and intimate forms of politeness are displayed).

\section{b) Grice's Theory}

The politeness is based on speaker and listener cooperation, namely cooperative principle. According to Grice as quoted by Watts (2005), politeness can be defined from cooperative principle. There are divided into four maxims. They are the maxim of quality, the maxim of quantity, the maxim of relevance, and the maxim of manner

(1) Maxim of quality, in which interacts should keep their conversational contributions as informative as is required for the purposes of the conversational exchange, but not more informative.

(2) Maxim of quantity: where one tries to be as informative as one possibly can, and gives as much information as is needed, and no more.

(3) Maxim of relevance, in which one should say only what they believe to be true or that for which they have adequate evidence.

(4) Maxim of manner, in which one should make their contributions relevant to the purposes of the overall conversation.

\section{c) Leech's Politeness Principles}

Leech provides us with the "Politeness Principle" (PP), delineated in his book Principles of Pragmatics (1983). Leech formulates the Politeness Principle by giving us a set of maxims. His concept is based on the terms self and other. In a conversation the self would be identified as the speaker (or anybody or anything close to the speaker), and the other would normally be identified as the hearer (or anybody or anything associated with the hearer). An interesting example related to who or what is considered to be a speaker (s), and who or what is considered to be a hearer ( $h$ ), and indeed one which may shed light on this division, is when referring to S's or H's spouse (Leech, 1983: 132): "S has to be more polite in referring to h's spouse than in referring to s's own spouse. Even in this area, however, there are cross-cultural variations: in some societies, a man discussing his wife will treat her as 'self', and therefore feeling free, perhaps even obliged, to denigrate her; but in other societies, he will treat her as 'other'."

\section{d) Cultural Values}

In the expression of culture, language is a fundamental aspect (Triyuni, et.al.: 2018). Human beings use language as a means of communication. Communication is always accompanied by interpretations containing meaning. From a discourse point of view, meaning is never absolute; always determined by various contexts always referring to the signs in human life in which there is culture. Therefore, language is never separated from the cultural context and its existence is always overshadowed by the culture (Dharma, et.al: 2018). Different culture causes different views of values, which affects the criteria of politeness and leads to differences in various themes. According to Huang (2014), there are many types in cultural differences such as ways to greet each other and farewells, addressing terms, ways to praise other, and ways to express thanks. When we are communicating with people from different cultures, it is best to know what is appropriate in their culture and act with regard to that, so as to avoid misunderstandings caused by culture differences. 


\section{Research Method}

This research is qualitative research. The research method is based on Dell Hymes's ethnographic communication theory, about the analysis of communication components, namely: "The Ethnography of Communication" which is then abbreviated to "The SPEAKING Grid" (Johnstone \& Marcellino, 2010: 7). The Components of communication or Components of communication include: Settings (situation / scene, topic, title), participants (persons), ends (purposes), act (how to organize the speech act, such as assertive, directives, commissive, expressive, declarative), key (tone or manner, such as: serious, sarcastic, jocular), instrument (channel, speech or writing), norms (socio-cultural rules), genre (recount, lecture, poem, descriptive). Furthermore, this method is also more specific to the Troike analysis model (Saville-troike, 2003).

The respondents in this study are the lecturers and the students in EFL classroom at Islamic College at Jakarta. The EFL Class is divided into three classes. They are class A (Speaking class with 22 students), class B (Reading and Vocabulary class with 23 students), and class C (Grammar class with 25 students). In this EFL classroom, the teaching and learning process takes place for 90 minutes. Observation, recording and interview are used in the data collection techniques.

Data analysis in this study is carried out by content analysis techniques with deductive procedures. This means that the data obtained are analyzed, then grouped into previously defined categories. Aspects of the interpretation of the text following the research questions are included in the categories. These categories can be revised and verified together with the course of the analysis process (Krippendorff, 2003). Miles et al. (1994) argue that analysis consists of three lines of activities that occur simultaneously, namely data reduction, data presentation, and conclusion or verification. Data reduction is defined as the selection process, focusing on simplification, abstracting, and transformation of rough data, which arises from written records in the field.

\section{Results and Discussion}

Communicating politely is not easy as many people fail in using polite language. If someone has the sincerity to maintain his dignity and self-esteem, there is a tone of intention to respect others, it is not impossible that everyone is able to speak politely. A person's language politeness can be seen in his attitude in respecting others.

There are seven cultural values of politeness in EFL class at Islamic College Jakarta:

\section{Glorifying God}

Glorifying God by saying greetings is included in the language culture of politeness. The courtesy addressed to religious matters concerning the glorification of God in the dialogue of English classroom is found in the following dialogues.

Situation: Before starting the lesson the lecturer (Class A) says greeting (salam), and the student answers the greeting (salam). Then the lecturer ask about the condition of the students.

Lecturer: Assalamu'alaikum warahmatullahi wabarakatuh, Good morning, boys and girls.

Student: Waalaikumsalam warahmatullahi wabarakatuh, Good morning Mam... Lecturer: I hope all of you feeling fine to day

Student: We hope so, Mam.

Lecturer: Hi, Qotrun. Are you feeling better now? You were sick yesterday, right? 
Student : Alhamdulillah, I am getting much better, Mam

Glorifying God with greetings is found in the opening speech of the lecturer Assalamu'alaikum warahmatullahi wabarakatuh when starting the lecture. The greeting is also answered by students on their turn with Waalaikumsalam warahmatullahi wabarakatuh. This utterance has a good meaning that is hopefully peace is bestowed on you accompanied by the mercy of Allah and blessings for you. Then students also deliver a speech Alhamdulillah which means in Arabic as all praise to God.

This statement above is expressed as a form of glorifying God and thanking God for giving us His blessing. Glorifying God in a speech is a culture of politeness in language, especially for the Muslims.

\section{2) Delivering Agreement}

Positive politeness can also be accomplished by being agreeable. Linguistic means of expressing this strategy are repetitions of what a preceding speaker has just said and positive back channel cues. Both repetition and positive back channel cues are widely used in a classroom context. It is important for learners to hear feedback from their teacher. These expressions serve not only to express positive politeness, but sometimes to provide corrective feedback; for example, a learner's mispronunciation. To demonstrate this strategy, we can refer to Figure 1, which shows the occurrence of "OK" as a positive back channel cue.

Situation: The students (Class A) has a presentation about home remedies, and then they have answer question session.

Student: Just choose, Mom.

Lecturer: Oh, just choose. Ok, Qotrun Why? You ask me to choose, and I choose you, because I love you.

Student: May I bring my book?

Lecturer: For glance is okay.

The Lecturer gives a response stating approval of requests submitted by students. Responses conveyed by speech For glance is okay. Saying yes or okay is an easy way to avoid conflict with the partner.

Another example can be found in the following dialogues.

Situation: The lecturer (Class B) discusses Religion and then he asks the questions to the students.

Lecturer: $\mathbf{O K}$. And then for purpose?

Student : Explain about the different things.

Lecturer: Explain different thing, ok? To describe a new different thing, around us. Then, the course?

The above statement expresses agreement on the answers given by addresses. Thus, the conversation above has indicated the existence of politeness in the language.

\section{3) Conveying an Apology}

Language politeness culture can be realized by conveying apologies. This culture of politeness is not found much, in learning only 2 turns of speech are found. Delivering forgiveness as a culture of politeness is found in the following example of transcription.

Situation: The Students (Class A) present their assignments about Home Remedies. After that a response is given by other students. 
Cultural Values of Politeness in EFL Classroom: A Study of Etnography of Communication, Fitriyah, Emzir, Sakura Ridwan

Student1: I think it would be very painful. No, I mean is it painful? Biting scars, or opening scars.

Student2: No, no, no. I mean beside.

Student1: Oh beside. I see. You didn't mention it before.

Student2: Sorry, sorry. I think you understand, that's good, that's good. Any more questions? Come on just ask me.

In English classes apologies are generally conveyed by the participants when giving incorrect answers or misunderstandings, but this apology is conveyed by students when they want to ask further questions to their lecturers. An apology expressing a desire to ask further is Sorry sir, where are you from?. This apologetic saying indicates that the speaker is polite and wants to get further answers from the addressee.

\section{4) Asking Questions}

Not every question has a language culture of politeness. Questions that have a culture of politeness begin with words like so, ok, yes. There are 47 of culture of politeness found in asking questions. From the 47 speech turns it can be seen in the following:

Situation. The Students (S) in Class A present their assignments about Home Remedies, then they responses from other students.

Student1: Okay guys, I want to tell you about my home remedies in my family. Okay, I don't know what's the name but I mention it poison antidote. From a bite of animal, like antipede. So, do you know centipede? Lipan in bahasa. Ok. In our family we have many traditional medicines to cure poisons. Do you know samsu?

Student2: ji samsu??

The culture of politeness in asking can be found in the speech above from Student1 saying So, do you know centipede? In this speech, the speaker conveys a question that does not require an answer from the other person, especially after that the speaker conveys the answer to his own question. This is done because the speaker wants to ask the attention of the addressee to speak on the topic he is talking about.

\section{Giving Praise}

Delivering praise to the speech partner is a culture of politeness in language.

Situation: Before starting the lesson, the lecturer (Class A) asks about the student's conditions.

Lecturer: Hi, Qotrun. Are you feeling better now? You were sick yesterday, right?

Student1: Alhamdulillah, I am getting much better, Mam

Lecturer: Good, and Agus, are you OK now?

Student2: Yes, Mam. I sometimes still feel dizzy, but I'm much better than I was yesterday.

The speech delivered by the lecturer is very polite because it directly gives appreciation and attention to students. A culture of politeness in the form of giving praise is also seen in the following:

Situation: The lecturer (class B) explains about grammar, and then asks the students about it.

Lecturer: Ok, the last, Ms. Ani?

Student: Still and steal.

Lecturer: Ya, good! Steal-stole-stolen. Steal and still. I still ... 
Student: Wood and would. Try and tray. Straight and strait

Lecturer: Ok, excellent, strait and straight.

The utterance $O k$. excellent delivered by the lecturer is a compliment addressed to students as a form of appreciation for being able to answer questions correctly.

\section{6) Delivering Thank You}

Thanking is one of the politeness of language in learning English. This culture of politeness is found in the conversations. Of the four speech shifts, one of them is as shown in the following conversation transcriptions.

Situation: The Students give their presentation in front of the class.

Lecturer: Ok. I think that's all ya? Thank you so much.

Student: Thank you so much guys.

Lecturer: Ok, thank you. Thank you for sharing!!! (and everybody claps their hands and cheers)

The politeness culture is realized by saying Thank you so much) by lecturer. This speech is delivered by the lecturer after students give their presentations as a form of appreciation for students. Then, the student says Thank you so much guys.

The student expresses his gratitude to his classmates after making a presentation as a tribute to their attention. Then the lecturer also says OK, thank you. Thank you for sharing !!! This speech is intended for students who have made presentations. Thank you is a universal culture and can be found anywhere and anytime in learning English.

\section{7) Praying for others}

Praying for others as a culture of language politeness is found in only one conversation. This data can be seen in the following:

Situation: Before starting the lesson, the lecturer (class A) gives greetings to students, and greetings are answered by students. After that the lecturer checks the condition of the student.

Lecturer: Assalamu'alaikum warahmatullahi wabarakatuh, Good morning, boys and girls..

Student: Waalaikumsalam warahmatullahi wabarakatuh, Good morning Mam...

Lecturer: I hope all of you feeling fine to day

Student: Amin. we hope so, Mam.

In addition to greetings as a prayer delivered by the Muslims, there are also prayers delivered by lecturers to students so that all are in good health. Speech that states this prayer is on the speech turn of the lecturer with the utterance of I hope all of you feel fine today; ubsequently responded by students by saying amin, we hope so, Mam. Speeches that convey good prayer to addressee in a communication indicate a politeness in language.

The data on language politeness culture in the dialogue on learning English at Islamic College Jakarta can be seen in the table 1 below.

Table 1. Distribution of Cultural Values of Politeness in EFL Class

\begin{tabular}{|c|l|c|c|}
\hline No & \multicolumn{1}{|c|}{ Cultural Values of Politeness } & Amount & Percentage \\
\hline 1 & Glorifying God & 14 & $5,17 \%$ \\
\hline 2 & Delivering Agreement & 50 & $43,10 \%$ \\
\hline 3 & Conveying an Apology & 2 & $1,72 \%$ \\
\hline 4 & Asking Questions & 47 & $40,51 \%$ \\
\hline
\end{tabular}




\begin{tabular}{|c|l|c|c|}
\hline 5 & Giving Praise & 6 & $3,44 \%$ \\
\hline 6 & Delivering Thank you & 7 & $5,17 \%$ \\
\hline 7 & Praying for others Amount & 1 & $0,86 \%$ \\
\hline & \multicolumn{1}{|c|}{ Am } & 116 & $100 \%$ \\
\hline
\end{tabular}

Based on table 1 above, the culture of politeness realized by expressing consent dominates when compared to other politeness cultures. This culture of politeness appears in 50 conversations with a percentage of $43.10 \%$. This high frequency indicates that this politeness culture is widely used by lecturers and students in dialogue in learning English. The politeness in the form of expressing consent is very dominating, this happens because this culture is not only used by lecturers, but also used by students. When the lecturer receives answers or explanations from the students, the lecturer responds: Ok, yes, yeah. Repeating answers from students is as a sign that the lecturer agrees at the student's answers. Likewise, students when lecturers provide explanations, opinions or questions, will also state their agreement by saying yes, yes Mam, yes Sir. No form of rejection is found on the side of the students when receiving explanations, opinions or questions from the lecturer. This could be so because of the position of students as actors who are learning and ready to receive knowledge from lecturers.

A culture of politeness whose frequency of appearance is low, is praying for other people, appearing only one time or $0.86 \%$. This shows that the sympathy of the lecturers to students has not yet been built

Every communication needs the subject matter to be discussed. The main problem becomes important in communication because it will be a guide in the discussion. However, sometimes if communication is only focused on the problem, without caring of the way of deliver, communication can be hampered. Therefore, in communication, the speech participants should not utter unpleasant speech and this is often called Face Threatening Acts (FTA) which means face-threatening actions. This is in line with the opinion expressed by Brown and Levinson that is to reduce the threat of our FTA in communication to use polite language.

There are various ways to display face salvation. In general, when we make a communication we have to respect the wishes of other people's faces. The face can be interpreted as a self-image that must be respected, respected by others. To save the faces of others, we can pay attention either to their positive or negative faces.

Then through the research, 12 conversations expressing sympathy are found. Utterances of sympathy as a positive politeness strategy are realized by the lecturer by saying thank you to students who have made a presentation. Thank you is also conveyed by students to lecturers and other students who have listened to the presentation. Utterances that begin with Salam means praying for all who are present to be given mercy, blessings, and peace from Allah SWT. The speech delivered by this student shows a communication process that maintains politeness and uses a strategy of positive politeness, because as a student, after giving the presentation, he should say thank you, because he has been given the opportunity and attention from the lecturer and other students.

\section{Conclusion}

Based on the data analysis and the result of the study, there are seven aspects of culture that influence the politeness strategies during the teaching-learning process in EFL class. It can be concluded that the kind of teacher-student interaction in the speaking class is reflected by 
lecturer's attitudes in giving questions, soliciting information and identifying the students' turns to answer.

Understanding the culture of politeness is important to achieve the better result in conducting classroom interaction in EFL class. The lecturer should use more politeness strategies actively and the students are then involved actively in the same way in the classroom. The students should create their own language expression and find the politeness strategies to get practiced in using language of politeness.

In addition, the lecturer should increase their cultural awareness in teaching EFL class. The students should increase their knowledge of politeness in English culture, through learning and practicing the language. Therefore, it would be better for the other researchers to conduct the study not only about politeness strategies in the EFL classroom but on the other point of views regarding politeness as well. Then, researchers are also expected to observe not only the interaction pattern between teacher students but also interaction one among students.

\section{Acknowledgements}

I wish to express my sincere gratitude the lecturers and the students, who have facilitated my research. I would also like to thank STFI Sadra (Islamic College) Jakarta and especially the director of STFI Sadra for his assistance in my completing this research.

\section{References}

Celce-murcia, M. (2007). Celce-Murcia, M. (2007).pdf. Intercultural Language Use and Language Learning, 41-57.

Dharma, A. T., Lubis, W. M., \& Syahra, N. A. (2018). Teenagers Cultural Values Towards Their Vernacular and Indonesian Languages. LANGUAGE LITERACY: Journal of Linguistics, Literature, and Language Teaching, 2(1), 68-77. https://doi.org/10.30743/II.v2i1.466

Ellis, R. (1997). Second Language Acquisition. USA: Oxford University Press.

Farrokhi, F., \& Arghami, M. (2017). An Investigation of the Use of politeness strategies in refusal among Characters with different power relations in English and Farsi Novels. International Journal of Applied Linguistics and English Literature, 6(7), 180. https://doi.org/10.7575/aiac.ijalel.v.6n.7p.180

Leech, Geoffrey N (1983). Geoffrey Leech-Principles of Pragmatics (Longman Linguistics Library) (1989).pdf.

Huang, Y. (2014). Politeness Principle in Cross-Culture Communication. English Language Teaching, 1(1), 96-101. https://doi.org/10.5539/elt.v1n1p96

Johnstone, B., \& Marcellino, W. M. (2010). Dell hymes and the ethnography of communication. The SAGE Handbook of Sociolinguistics, (May), 57-66. https://doi.org/10.4135/9781446200957.n4

Krippendorff, K. (2003). Content Analysis: An Introduction to Its Methodology Ch2 and 4. Content Analysis: An Introduction to Its Methodology. Retrieved from http://www.uk.sagepub.com/textbooks/Book234903

Miles, M. B., \& A. Huberman, M. (1994). Qualitative Data Analysis, An expanded Sourcebook 2nd Edition.

Peng, L., Xie, F., \& Cai, L. (2014). A Case Study of College Teacher' s Politeness Strategy in EFL Classroom, 4(1), 110-115. https://doi.org/10.4304/tpls.4.1.110-115

Saville-troike, M. (2003). The Ethnography of Communication, third edition. Blackwell Publishing. 
Cultural Values of Politeness in EFL Classroom: A Study of Etnography of Communication, Fitriyah, Emzir, Sakura Ridwan

Senowarsito. (2013). Politeness Strategies in teacher-student interaction in an EFL classroom context. TEFLIN Journal, 24, 82-96. https://doi.org/10.15639/TEFLINJOURNAL.V24I1/82-96

Triyuni, D., Fadhilla, F., \& Putri, L. W. (2018). Teenagers Perception toward Language Use in Public Place Advertisement. LANGUAGE LITERACY: Journal of Linguistics, Literature, and Language Teaching, 2(2), 151. https://doi.org/10.30743/Il.v2i2.648

Watts, Richard, J., Ide, I., Sachiko, S., Lich, E.-, \& Konrad, K. (2005). Politeness in Language. 